\title{
ХАРАКТЕРИСТИКА ОКРЕМИХ ЕЛЕМЕНТІВ СИСТЕМИ ОБСТАВИН, ЯКІ ПІДЛЯГАЮТЬ ДОКАЗУВАННЮ ПІД ЧАС ДОСУДОВОГО РОЗСЛІДУВАННЯ ДОРОЖНЬО-ТРАНСПОРТНИХ ПРИГОД
}

Берназ П. В.

\begin{abstract}
У статті акцентовано увагу на активних наукових пошуках, які здійснюються вченими у межах заключного розділу криміналістики - криміналістичної методики розслідування злочинів. Акцентовано увагу на тому, що значна кількість таких наукових розробок спрямована на уточнення положень сформованих та усталених методик розслідування, що зумовлено постійними змінами у злочинній діяльності. Наголошено, що невід'ємним елементом будьякої методики розслідування злочинів є система обставин, які підлягають установленню, яка корелюється із системою обставин, котрі підлягають
\end{abstract} доказуванню під час розслідування кримінального провадження. Виокремлено чинники, які впливають на постійну актуальність наукового дослідження обставин, які підлягають встановленню та доказуванню під час розслідування дорожньо-транспортних пригод. Окреслено останні публікації за вказаною проблематикою. Звернено увагу на те, що наведена у кримінальному процесуальному законодавстві система обставин, які підлягають встановленню, $\epsilon$ загальною для всіх видів кримінальних правопорушень і повинна у межах конкретного кримінального провадження доповнюватися ознаками конкретного злочину, визначеними у межах кримінального закону. Обґрунтовано, що за своєю структурою дорожньо-транспортна подія є складним явищем, яке включає значну кількість елементів. У контексті цього наголошено, що особливо вагоме значення має встановлення механізму злочину. Виокремлено елементи, які взаємодіють між собою під час вчинення дорожньо-транспортних пригод. Особливу увагу звернено на використання дорожньо-транспортних пригод як способу інсценування та приховування інших кримінальних правопорушень, зокрема умисних вбивств. Проаналізовано значення встановлення точного місця дорожньо-транспортної пригоди, а також огляд місця події як першочергової та невідкладної слідчої дії під час розслідування таких правопорушень. Окрім того, особливу увагу звернено на необхідність установлення точного часу вчинення злочину та його взаємозв'язку з іншими елементами подіі. Детально охарактеризовано систему обставин, які підлягають встановленню щодо водія тран- спортного засобу - учасника дорожньо-транспортної пригодu.

Ключові слова: досудове розслідування, доказування, дорожньо-транспортна пригода, місце вчинення злочину, час учинення злочину, інсценування злочину.

Bernaz P. V. Characteristics of individual elements of the system of circumstances, which are subjected to proving during the pre-trial investigation of road traffic accidents

The article focuses on the active scientific research carried out by scientists within the final section of criminology - forensic methods of crime investigation. Emphasis is placed on the fact that a significant number of such scientific developments are aimed at clarifying the provisions of established and established methods of investigation, due to the constant changes in criminal activity. It is emphasized that an integral element of any method of investigating crimes is the system of circumstances to be established, which correlates with the system of circumstances to be proved during the investigation of criminal proceedings. The factors influencing the constant relevance of the scientific research of the circumstances to be established and proved during the investigation of road accidents are singled out. The latest publications on this issue are outlined. Attention is drawn to the fact that the system of circumstances to be established in the criminal procedure legislation is common to all types of criminal offenses and must be supplemented within the specific criminal proceedings by the features of a specific crime defined within the criminal law. It is substantiated that by its structure a traffic accident is a complex phenomenon that includes a significant number of elements. In this context, it is emphasized that the establishment of the mechanism of the crime is of particular importance. Elements that interact with each other during road accidents are highlighted. Particular attention is paid to the use of road accidents as a way of staging and concealing other criminal offenses, including premeditated murder. The importance of establishing the exact location of the accident, as well as an overview 
of the scene as a priority and urgent investigative action during the investigation of such offenses. In addition, special attention is paid to the need to establish the exact time of the crime and its relationship with other elements of the event. The system of circumstances to be established in relation to the driver of the vehicle - a participant in a traffic accident is described in detail.

Key words: pre-trial investigation, evidence, traffic accident, place of crime, time of crime, staging of a crime.

Постановка проблеми та її актуальність. Тенденції розвитку сучасної криміналістичної науки свідчать про активні наукові пошуки у межах заключного розділу криміналістики - криміналістичної методики розслідування злочинів. Аналіз наукових досліджень останніх років свідчить, що на порядку денному серед науковців знаходяться питання класифікації криміналістичних методик розслідування, визначення структури криміналістичної методики розслідування злочинів, розроблення нових методик розслідування, а також уточнення положень існуючих видових, міжвидових, підвидових та позавидових методик розслідування злочинів. При цьому, як свідчить опрацювання наукових джерел та матеріалів практики, навіть традиційна злочинна діяльність як відповідна система зазнає суттєвих змін, що потребує перегляду окремих положень методик розслідування, які давно розроблені у межах криміналістики та $є$ доволі усталеними. Однією із таких криміналістичних методик $\epsilon$ методика розслідування дорожньо-транспортних пригод, яка достатньо ґрунтовно розроблена у межах криміналістичної науки. Не вдаючись до наукової дискусії щодо структури такої методики розслідування, на нашу думку, невід'ємним ії складником є система обставин, які підлягають установленню, котра прямо корелюється з обставинами, які підлягають доказуванню у кримінальному провадженні згідно зі ст. 91 КПК України. Безумовно, вченими неодноразово приділялась увага аналізу таких обставин, але актуальність цієї проблеми не зменшується, що зумовлено такими чинниками: по-перше, якісною трансформацією транспортних засобів, що призводить до суттєвих змін у механізмі слідоутворення i, як наслідок, впливає на особливості доказування окремих складових злочину; по-друге, використанням оперативно-слідчими підрозділами інноваційних технічних засобів під час огляду місця дорожньо-транспортних пригод; активізацією протидії досудовому розслідуванню таких злочинів на початковому етапі, зокрема безпосередньо під час огляду місця події, тощо. Наведене і зумовлює актуальність та своєчасність представленої наукової публікації.

Аналіз останніх досліджень і публікацій. Останнім часом проблеми методики розслідування злочинів, а також доказування під час розслідування кримінальних проваджень щодо дорожньотранспортних пригод досліджували: Ю.П. Аленін, Л.І. Аркуша, А.М. Анохіна, В.П. Бахін, В.Д. Берназ, А.Ф. Волобуєв, В.А. Журавель, А.В. Іщенко, Н.І. Клименко, В.О. Коновалова, М.П. Климчук, В.Ю. Крупей, І.І. Колесник, І.М. Лузгін, П.П. Луцюк, П.С. Луцюк, В.В. Лисенко, Г.А. Матусовський, В.О. Образцов, М.В. Салтевський, М.О. Селіванов, Р.Л. Степанюк, В.В. Тіщенко, Ю.М. Чорноус, В.М. Шевчук, В.Ю. Шепітько, Б.В. Щур, М.П. Яблоков та інші вчені.

Виклад основного матеріалу. Відповідно до ч. 1 ст. 91 КПК України, у кримінальному провадженні підлягають доказуванню: подія кримінального правопорушення (час, місце, спосіб та інші обставини вчинення кримінального правопорушення); винуватість обвинуваченого у вчиненні кримінального правопорушення, форма вини, мотив і мета вчиненого кримінального правопорушення; вид і розмір шкоди, завданої кримінальним правопорушенням, а також розмір процесуальних витрат; обставини, які впливають на ступінь тяжкості кримінального правопорушення, характеризують особу обвинуваченого, обтяжують чи пом'якшують покарання, які виключають кримінальну відповідальність або є підставою для закриття кримінального провадження; обставини, що $€$ підставою для звільнення від кримінальної відповідальності або покарання; обставини, які підтверджують, що гроші, цінності та інше майно, які підлягають спеціальній конфіскації, одержані внаслідок учинення кримінального правопорушення та/або є доходами від такого майна, або призначалися (використовувалися) для схиляння особи до вчинення кримінального правопорушення, фінансування та/або матеріального забезпечення кримінального правопорушення чи винагороди за його вчинення, або $є$ предметом кримінального правопорушення, у тому числі пов'язаного з їх незаконним обігом, або підшукані, виготовлені, пристосовані або використанні як засоби чи знаряддя вчинення кримінального правопорушення; обставини, що $\epsilon$ підставою застосування до юридичних осіб заходів кримінально-правового характеру.

Наведений у КПК України перелік обставин $\epsilon$ загальним для будь-якого виду кримінального правопорушення, а під час розслідування конкретного виду злочину слідчий орієнтується на 
відповідні елементи, які $є$ ключовими саме для цього виду злочину, i, як наслідок, формулює систему обставин, які підлягають установленню під час досудового розслідування. Окрім того, для конкретизації змісту наведеного переліку обставин під час розслідування конкретного злочину необхідно враховувати не лише положення ст. 91 КПК України, а й положення кримінального закону, що визначають юридично значущі обставини, необхідні для правильної кваліфікації кримінального правопорушення, а також особливості криміналістичної характеристики таких діянь.

Так, обов'язковим для доказування $\epsilon$ подія кримінального правопорушення, що прямо корелюється 3 установленням слідчим конкретних обставин злочину. Як видно з аналізу норм КПК України, для доказування події кримінального правопорушення обов'язковим $\epsilon$ встановлення способу вчинення злочину. Необхідно зауважити, що дорожньо-транспортна пригода за структурою являє собою багатогранне явище й їі різновиди залежать від складного комплексу факторів, що характеризуються, з одного боку, дорожньою обстановкою (ситуацією), а з іншого - особистістю учасників руху. Безпека руху зумовлена надійністю елементів системи «водій - автомобіль (транспортний засіб) - дорога - середовище у їх взаємодії». Самостійним елементом у механізмі дорожньо-транспортної події слід виділити поведінку інших учасників дорожнього руху (пішоходів, пасажирів, водіїв інших транспортних засобів) [5]. Саме тому видається, що необхідно акцентувати увагу на необхідності з метою доказування встановлення механізму дорожньо-транспортної пригоди.

Так, на думку О.Н. Колесніченка, механізм учинення злочину - це порядок (головним чином, тимчасового і динамічного) зв'язку окремих етапів, обставин, факторів самої події злочину, що дає змогу відтворити його картину [4]. Своєю чергою, O.В. Самойлов відзначає, що механізм учинення злочину - це системний, складний, динамічний порядок взаємодії криміналістично важливих елементів злочинної діяльності, суб'єкта і факторів об'єктивної дійсності, які визначають зміст злочинної діяльності і зумовлюють виникнення криміналістично значимої інформації [7]. Водночас необхідно звернути увагу, що механізм ДТП не $\epsilon$ тотожним категорії механізму вчинення злочину, оскільки ДТП є наслідком порушення відповідної правової заборони та/або певного суб'єктивного фактору. Тому слушно погодитися з дослідниками, які відзначають, що ДТП - це послідовність розвитку дорожньої ситуації за часом і положенням учасників, під час якої стався збій у системі «водій - транспортний засіб - дорога - навколишнє середовище» і в результаті чого настали суспільно небезпечні наслідки. Таким чином, у механізмі ДТП виділяється кілька елементів, які взаємодіють між собою:

водій (його кваліфікація, досвід роботи, стан здоров'я, термін перебування за кермом тощо);

транспортний засіб (його технічний стан);

дорога (стан дорожнього покриття, рельєф, наявність або відсутність дорожніх знаків тощо);

- навколишнє середовище (перешкоди, у тому числі інші транспортні засоби, погодні умови, пішоходи, оглядовість траси тощо) [3].

Зважаючи на викладене, встановлення під час досудового розслідування механізму дорожньо-транспортної події $є$ основою для подальшого доказування під час досудового розслідування та формування обвинувачення щодо особи. Окрім того, особливу увагу необхідно звернути на необхідність ужиття слідчим усіх заходів, спрямованих на встановлення механізму ДТП, оскільки це забезпечує правильну кваліфікацію дій особи, оскільки у структурі злочинної діяльності дорожньо-транспортні пригоди можуть виступати самостійним елементом, спрямованим на приховування злочину шляхом інсценування. Як відзначає Ю.І. Осадчий, інсценування дорожньо-транспортної події може бути складником способу вчинення та приховування наслідків вчинення вбивств (наприклад, вбивств на замовлення, замаскованих під дорожньо-транспортну подію) [6]. У контексті цього слушно погодитися з дослідниками, які наголошують на доцільності ретельного огляду місця події із залученням відповідних фахівців, фіксації усіх змін в обстановці, проведення попереднього дослідження виявленої та вилученої слідової інформації [1]. Зважаючи на те, що огляд місця події $\epsilon$ невідкладною слідчою дією, його слід проводити якнайшвидше після повідомлення про ДТП. Його проведення обов'язково потребує спеціальних знань (переважно в галузі автотехніки, трасологіi), а отже, залучення відповідних спеціалістів, що особливо важливо у разі зникнення з місця події особи, яка порушила правила безпеки дорожнього руху [10].

У контексті доказування події дорожньо-транспортної пригоди під час досудового розслідування має місце вчинення злочину. У контексті цього необхідно максимально точно встановити просторові межі, в яких відбулася подія злочину. Точне встановлення місця вчинення злочину дає 
можливість не лише з'ясувати повну картину події злочину, а й виявити наявні сліди злочину, речові докази, встановити очевидців події.

Криміналістами справедливо відзначається, що встановлення точного місця вчинення злочину також $є$ необхідним для перевірки показань обвинуваченого, потерпілого, свідків, у тому числі для перевірки алібі. Якщо злочинець невідомий потерпілому, то встановлення точного місця вчинення злочину й особливостей прилеглої території допомагає слідчому в установленні свідків події [2].

Не менш важливим $€$ встановлення і точного часу дорожньо-транспортної події, зокрема години, у межах якої відбулася дорожньо-транспортна пригода. Установлення точного часу ДТП має ключове значення перш за все у контексті його взаємозв' язку з іншими умовами об'єктивної дійсності, які закономірно існують лише у відповідні часові проміжки. Окрім того, встановлення точного часу ДТП $є$ необхідним для: по-перше, якісного призначення та проведення судових експертиз, пов'язаних із визначенням механізму дорожньо-транспортної події; по-друге, подальшого проведення окремих слідчих (розшукових) дій, оскільки під час розслідування злочинів цієї категорії, наприклад, така слідча (розшукова) дія, як слідчий експеримент, повинна бути проведена у максимально наближених умовах до умов, які існували на момент учинення злочину, фактично у разі вчинення ДТП у нічний час із метою забезпечення точності отримання фактичних даних під час проведення слідчого експерименту останній має бути також проведений у нічний час. Окрім того, встановлення точного часу ДТП має велике значення під час оцінки особи злочинця, зокрема його медичних та інших особистих показників, які впливають на здатність виконання функції керування транспортним засобом у різні часові проміжки. Загалом з організаційного боку встановлення точного часу вчинення злочину можливо шляхом допиту свідків, потерпілого, підозрюваного під час огляду місця події, за результатами освідування або судово-медичної експертизи, а також за допомогою інших слідчих (розшукових) дій.

Наступним елементом, який підлягає доказуванню, $є$ винуватість особи у вчиненні кримінального правопорушення. У контексті цього необхідно зауважити, що вся діяльність органів кримінального переслідування спрямована на встановлення винуватості особи, тому у доказуванні цього елементу під час розслідування ДТП встановленню підлягає значний обсяг обставин, які неможливо проаналізувати у межах даної наукової статті.
Водночас, зважаючи на особливості злочинів цієї категорії, звернімо увагу на обставини, які мають бути встановлені щодо водія транспортного засобу, який є учасником ДТП, зокрема:

nо-перше, факт реального знаходження особи за кермом транспортного засобу та керування ним, унаслідок чого сталося ДТП. Слідча практика, особливо в контексті діяльності слідчих ДБР, свідчить, що в окремих випадках водії транспортного засобу під час прибуття на місце події слідчо-оперативної групи повідомляють, що транспортним засобом керувала інша особа, зокрема особа, яка загинула під час дорожньо-транспортної пригоди. Як відзначають дослідники, одним із ключових питань, яке найчастіше ставлять на вирішення комплексної експертизи, є встановлення особи, котра перебувала за кермом транспортного засобу на момент виникнення дорожньо-транспортної пригоди. Дана проблема виникає у тому разі, коли слідчий на місці події не має можливості встановити особу, яка перебувала за кермом транспортного засобу. Така ситуація зазвичай виникає тоді, коли покази свідків різняться між собою, а водій, причетний до дорожньо-транспортної пригоди, намагаючись приховати свою участь у даній події, стверджує, що за кермом автомобіля перебувала особа, яка загинула. Експерти після відтворення шляху і характеру руху транспортного засобу під час пригоди визначають напрями сил, які діють на осіб, що знаходилися в транспортному засобі, та пробують установити, які частини тіла осіб, що займали конкретні місця в транспортному засобі, могли увійти в контакт із відповідними елементами внутрішнього інтер'єру автомобіля.

Під час виконання експертного дослідження враховується механізм травми водія: удар об кермо автомобіля руками та передньою поверхнею грудної клітки та живота, ступнями - об педалі керування, нахил голови та тулуба вперед, поступальний рух уперед, удар ділянкою колінного суглоба об панель керування під час піднімання із сидіння та поступального переміщення траєкторією дуги вперед та вверх, що супроводжується ударом стегон об кермо, волосистою частиною голови потерпілих високого зросту в дах, а потерпілих низького зросту - ділянкою обличчя в лобове скло, після чого відкидається назад з ударом у спинку або подушку сидіння в момент повернення в крісло [8];

по-друге, знаходження водія під час вчинення ДТП у станах, викликаних уживанням алкогольних напоїв, психотропних речовин та/або наркотичних засобів та інших речовин. У контексті 
цього, як свідчить практика, особливу складність викликає встановлення факту перебування водія під впливом седативних препаратів - лікарських засобів, що здійснюють заспокійливу дію на центральну нервову систему, істотно не впливаючи на звичайні функції, які відпускаються без рецепту лікаря та не заборонені у вільному продажі. Водночас дія таких препаратів на нервову систему людини характеризується частковою втратою концентрації, уваги, здатності швидко реагувати на раптові зміни, що має ключове значення під час керування транспортним засобом;

no-mpeme, стан здоров'я водія транспортного засобу під час учинення ДТП. Так, 19 вересня 2013 р. у Львові на вулиці Дорошенка водій легкового автомобіля виїхав на зустрічну смугу руху, де зіткнувся з іншим легковиком i автобусом. Установлено, що водій помер ще до аварії через інфаркт [9];

nо-четверте, професійні навики водія, зокрема: а) стаж водіння транспортного засобу; б) досвід водіння транспортного засобу відповідної категорії; в) досвід водіння транспортного засобу з конкретними конструктивними особливостями управління (наприклад, механічна/автоматична коробка передач тощо);

no-n'яте, наявність у водія досвіду роботи у правоохоронних органах, оскільки у разі виникнення логічних суперечностей під час дослідження механізму ДТП може бути висунута версія щодо внесення особою змін у місце події, зважаючи на наявність професійного досвіду роботи у відповідній сфері.

Висновки. Підсумовуючи викладене, необхідно відзначити, що, незважаючи на традиційність злочинів, пов'язаних із порушенням правил дорожнього руху та експлуатації транспорту, а також розробленість методик їх розслідування, аналіз слідчої практики свідчить про наявність значної кількості проблем, які виникають у працівників слідчих підрозділів у доказуванні під час здійснення досудового розслідування, що зумовлено: якісною зміною транспортних засобів; активізацією протидії розслідуванню таких злочинів на початковому етапі з боку водіїв транспортних засобів; появою нових чинників, які впливають на поведінку водіїв під час керування транспортними засобами, які не знайшли досі ґрунтовного наукового дослідження у контексті доказування (вживання водіями окремих видів медичних препаратів, використання різних видів технічних засобів під час керування транспортними засобами, зокрема засобів стільникового зв'язку тощо); появою нових видів криміналістичної тех- ніки, яка використовується під час установлення обставин такого кримінального правопорушення; конструктивними змінами у транспортних засобах, які спрощують установлення окремих даних щодо механізму дорожньо-транспортної пригоди, зокрема встановлення точної швидкості автомобіля під час зіткнення, щодо яких не має однозначної судової практики у разі їх використання у доказувані.

\section{Література}

1. Аксьонов В.В., Кожевніков В.В. До проблеми встановлення факту інсценувань злочинів. Криміналістичний вісник. 2017. № 1. С. 117-123.

2. Карева А.А., Дубровин С.В. Предмет доказывания при расследовании умышленного причинения вреда здоровью. Закон и право. 2006. № 2. С. 27-29.

3. Колесник І.І. Аналіз механізму дорожньо-транспортної пригоди як основа розслідування злочинів проти безпеки дорожнього руху та експлуатації транспорту. Вісник Національного університету імені В.Н. Каразіна. Серія «Право». 2016. Вип. 21. С. 252-254.

4. Колесниченко А.Н. Общие положения методики расследования отдельных видов пре ступлений : лекция. Харьков : Харьк. юрид. ин-т, 1976. 28 с.

5. Криміналістика : підручник. Одеса : Гельветика, 2017. 556 с.

6. Осадчий Ю.І. Типові слідчі ситуації та напрями розслідування окремих злочинів, пов' язаних з інсценуванням дорожньо-транспортної події. Південноукраїнський правничий часопис. 2017. № 4. С. 58-60.

7. Самойлов А.В. Установление механизма совершения кражи в процессе расследования : монография. Москва : Юрлитинформ. 2010. 152 с.

8. Судова експертиза: проблеми сьогодення та перспективи розвитку : колективна монографія / Львівський науково-дослідний інститут судових експертиз. 2020. 406 с.

9. У Львові водій авто помер за кермом. URL: https://zaxid.net/u_lvovi_vodiy_avto_pomer_za_ kermom_n1293893/amp.

10. Ховпун О.С. Особливості огляду місця ДТП в умовах протиправного зникнення водія автотранспортного засоби з місця події. Часопис академії адвокатури України. 2011. № 13. С. 1-6.

Берназ П. В., кандидат юридичних наук, доцент, проректор з навчальної роботи одеського державного університету внутрішніх справ 